\title{
AGE DISCRIMINATION IN EMPLOYMENT: AN FEPC MISFIT
}

OLDER workers frequently suffer employer disfavor. Because the seniority system $^{1}$ and the practice of placing old employees in less demanding jobs" tend to protect the worker once he is employed, age discrimination occurs primarily in hiring rather than in firing. ${ }^{3}$ Employment notices often contain specific age restrictions; alternatively, age limits are maintained by unwritten rules. ${ }^{4}$ Such discrimination wastes a valuable labor resource, increases the public's social security burdens, and undermines the psychological as well as the economic well-being of the worker himself.5 These problems are magnified by the growing proportion of older people in the population. ${ }^{\circ}$

Opponents of age discrimination have in the past waged their battle chiefly

1. Over three fourths of 330 collective bargaining agreements analyzed recently by the Bureau of Labor Statistics made seniority a factor in determining the order of layoff. In about 60 per cent of the agreements seniority alone governed the order of layoff, provided that the older worker was competent to do available work. Nix; Collectively Bargained Length of Service Benefits, 73 U.S. DeP'T. LABor MonTHLY LAB. REv. 152, (1951) (hereinafter cited as Monthly LAB. REv.).

2. This is often done voluntarily by the employer. See Clague, Older Workers: Industrial Aspects of Aging, 70 Montely Lab. Rev. 506 (1950). Moreover some collective bargaining agreements contain clauses requiring employers to place older employees in light jobs. Bureau of Labor Statistics, Fact Book on the Employsuent Promlems of Oider Workers 17-20 (1950). See also Wages and Hours of Labor, 44 MONTHLY LAB. REv. 688, 702 (1937).

3. See Bureau of Employment Security, Older Workers Seek Jons-Survey in Four Public Employment Service Offices 2 (1951), where the conclusion is reached that although "the older worker remains out of a job for a longer period of time than his younger shopmates... [h] is job tenure... is no less secure." See also BARkiN, Tine Older Worker in Industry-A Study of New York State Manufacturing Industries 179 (1933) ; Beveridge, Fuli. EMployment in a Free Soctetr 70 (1944).

4. See, e.g., Bureau of Employment Security, op. cit. sulpra note 3, at 9. Age restrictions were found in 72 per cent of the job openings in Columbus, Ohio; 60 per cent of the openings in Lancaster, Pennsylvania; 51 per cent in Houston, Texas; and $25 \mathrm{per}$ cent in New York City. However, a New York survey during the depression period showed 72 per cent of manufacturing industries investigated had discriminatory age hiring policies. Barkin, op. cit. supra note 3, at 190. See also Californin Depaktnent of Industrial Relations Spectal Bulletin No. 2, Middle-Aged and Older Workess in CaLIFoRnIA 19 (1930), where only 11 per cent of all firms investigated were found to have maximum age limits for hiring.

5. See H.R. 4731, 82d Cong., 1st Sess. $\$ 2$ (a) (1951; Carlson, The Older Worlicr, 57 Sa. Montruy 5 (1943); Hamilton, Changes in Personality and Psychosenual Phenometra with Age in Problexs of Agetng 810, 817. (Cowdry ed., 2d ed. 1942).

6. Between 1900 and 1950 the number in the forty-five to sixty-five age group tripled, and their proportion in the total population increased from one in seven to one in five. In that same period the number of persons aged sixty-five or over almost quadrupled and their proportion in the population inoreased from one in twenty-five to one in thirteen. These changes are generally attributed to the decline in the birth rate, the 
by persuasion and agreement. Welfare organizations attempt to encourage employers to place older workers. ${ }^{7}$ Federal and state governments aid these activities, ${ }^{8}$ and older workers themselves have organized not only to find jobs but also to create work opportunities. ${ }^{9} \mathrm{~A}$ more recent method of fighting age

increase in longevity due to medical science and higher living standards, and the cessation of large-scale immigration. Buread of Lazor Statistics, op. cit. sipra note 2, at 1.

The Commissioner of Labor Statistics asserts that the problem of the older vorker is caused by the interaction of two factors: (1) rapid technologieal changes in industry which render the skills of older workers obsolete, and (2) the growing number of older workers in the labor force. Clague, Employment Problems of the Older Worker, 65 MONTHLY LAB. REv. 661 (1947).

7. See, e.g., Michael, Job Sleuths for the Middle-Aged, Coronet, Oct. 1949, p. 165; After 40 What? Services of the Presidents' Gatidance Bureau of San Franciseo, 23 School LIFE 360 (1938); Waggaman, Older Workers in IVarlime, 59 M10:iruLY LAD. REv. 24, 34 (1944).

8. The efforts of the federal government are mainly informational and exhortatory. See, e.g., the proclamation by President Roosevelt designating National Employment Week "to the end that interest in the welfare of all those not now working, and especially the worker over 40, may be stimulated and employment extended to them." Exee. Order No. 8729, 6 FED. REg. 1791 (1941). Much of this work is carried on by the Department of Labor in the Bureau of Employment Security and the Bureau of Labor Statistics. While more direct action is rare, in a notable exception efforts of the Veterans Placement Service of the Bureau of Employment Security raised the permanent placements of older workers in Toledo 11 per cent in one year. Toledo Plans for Placing Veterans, 51 Monthly Lab. Rev. 1120, 1121 (1940). On the other hand the government itself maintains age limits for many of its own job qualifications. See, c.g., Moximum Age for Civil-Service Positions Under National Defense, 52 Moxthly LAв. Rev. 1385 (1941).

California and Pennsylvania have experimented with the practice of publishing the names of employers who do not have policies of age discrimination. Calrfon:ris DepartaIENT of InDUstrual Relations, op. cit. supra note 4, at 83-93; Abolisling a Defirite Age Linit in Employment, Monthly Labor Review, Dec. 1928, p. 93. New Yorl: has tried rehabilitation programs for older workers. Unemployment of Older II"orkers in $\mathrm{N}$ crv York, 49 Monteny LAB. Rev. 364 (1939). Bills are now pending before the New York Legislature to establish an adult health and geriatrics program and an advisory council on empoyment of older workers to combat age barriers. N.Y. Times, February 15, 1952, p. 13, col. 1 .

9. Best known are the "40 plus" clubs. These are groups of unemployed executives who once earned at least $\$ 4,000$ per year. Miembers interview prospective employers with the purpose of getting jobs for their fellow members rather than for themselves. Waggaman, New Techniguses for Getting Jobs, 50 Monthly LAB. KEv. 797, 804 (1940). See also Giles, Hired After Forty-Boston Style, Reader's Digest, Dec. 1938, p. 1.; and Recent Activities of New York Forty Plus Clab, 51 Montmly LAB. Rev. 623 (1941). These clubs have provided the impetus for similar activities by other groups. See Business Week, Aug. 13, 1938, pp. 30-1; and Los Angeles 40-plus Club for Womcn, 53 MonruuY LAB. REv. 393 (1940).

Workers' co-ops composed mainly of older workers, arose on the west cosst during the depression. These "self-help" co-ops engage chiefly in the barter of their labor for goods. Mlembers work mainly as farmers, common laborers, dressmaliers and kitchen helpers. Panunzio, Church, \& Wasserasan, Selp-Help Cooperatives in Los Asiceies (1939). See also Self-Help Coopiratizes for Older Workers, 48 Mfostaly Lab. Rev. 1081 (1939). 
discrimination is to include clauses in collectively bargained agreements requiring employers either to abolish age limits in hiring or to hire a specified proportion of older workers. ${ }^{10}$

Two legislatures have recently moved to supplement these efforts. In Massachusetts, the Fair Employment Practices Commission law was amended to make age as well as race, color, religion, national origin and ancestry an illegal ground for discrimination in hiring, firing, or conditions of employment.11 Discrimination is allowed only when based on a "bona fide occupational qualification." 12 A bill to prohibit age discrimination has also been introduced in Congress. ${ }^{13}$ Both measures provide similar procedure for processing complaints. Either the agency or an individual may file a charge of cliscrimina-

10. Bureau of Labor Statistics, op. cit. sipra note 2, at 17-18. Such clauses were, however, found in only one per cent of 2,425 contracts examined by the Burealu.

11. Acts of 1950 c. 697, Mass. Ans. Laws c. 151B (Supp. 1951). The amendment originated in a bill filed by the Massachusetts Federation of Labor. Kelley, Thic Bay State Pioneers, The American Federationist, Nov. 1950, p. 14. There is some question as to how thoroughly it was considered by the legislature.

"For months the battle [over the age amendment] raged at the State House." Ibid.

"There was singularly little discussion of [the age amendment] and no opposition." Communication to the Yale LAw Journal from Mildred H. Mahoney, Chairman of the Massachusetts Commission Against Discrimination, dated October 10, 1951, on file in Yale Law Library.

Massachusetts also has another law prohibiting age discrimination. MASs. ANN. LAwS c. $149 \$ 24 \mathrm{~A}-\mathrm{J}(1950)$. This law, passed in 1937 , declares that discrimination against people forty-five to sixty-five in hiring or firing is against public policy. $1 d$. $\$ 24 \mathrm{~A}$. It voids the provisions of any contract which promotes such discrimination. $I d . \$ 24 \mathrm{~B}$. Employers are required to keep records of the ages of their employees. Id. $\S 24 \mathrm{D}$. The commissioner of Labor and Industries is authorized to hold hearings to determine the existence of age discrimination. $I d$. $\$ 24 \mathrm{G}$. Upon a finding of discrimination, the commissioner may publish the name of the offending employer in newspapers. Ilid. But neither the commissioner, his representatives, the "newspaper publisher, proprietors, editor, nor employee" are immunized from a damage action for wilful misrepresentation. Ibid. The law was applied in only two cases in thirteen years, Kelley, Massachusetts Law Against Age Discrimination in Employment, in N. Y. Legrs. Doc. No. 12, No Time to Grow Old 173 (1951).

Louisiana had previously passed a law making age discrimination against workers under fifty a misdemeanor punishable by a fine of up to $\$ 500$ or by imprisonment up to 90 days or both. Louisiana Acts 1934, No. $226 \$ 1-3$, LA. Rev. Stat. tit. 23, \$§ 892-3 (1950). This law, as well as the earlier Massachusetts statute, was characterized by the New York Commission studying the age problem as "[not] even partially effective." Findings and Recommtendations of the New York State Joint Legislative Commiltec on Problems of Aging in. N. Y. Legrs. Doc. No. 12, No Tine to Grow Ot.v 29 (1951).

12. Mass. ANn. Laws c. $151 \mathrm{~B}, \S 4$ (1950). This provision was part of the law prior to the age amendment.

13. Three identical bills were introduced July 9, 1951 : H.R. 4731, 82d Cong., 1st Sess. by Representative Jacob Javits, R., N.Y.; H.R. 4733, 82d Cong., 1st Sess. by Representative James Fulton, R., Pa.; and H.R. 4734, 82d Cong., 1st Sess. by Representative Albert Morano, R., Conn. For simplicity, references in this note will be to H.R. 4731. 
tion. ${ }^{14}$ If the agency finds probable cause for the charge, it first attempts to eliminate the discrimination by informal methods of conference and persuasion. Should these fail a formal hearing is called. ${ }^{15}$ Upon a finding of unjustified discrimination because of age, the agency can issue a cease and desist order and take other affirmative action such as compelling reinstatement or hiring. ${ }^{10}$ The legislation also provides for review and enforcement by the courts. ${ }^{17}$ In addition, Massachusetts sets up criminal penalties for wilful violation of a final order issued by its Commission Against Discrimination. ${ }^{18}$

Neither measure is broad enough to deal with the whole problem of the older worker. The Massachusetts law applies only to workers between fortyfive and sixty-five, and the federal bill is probably limited to workers over forty-five. ${ }^{19}$ But there is ample evidence of age discrimination against workers under forty-five, particularly in the case of women. ${ }^{20}$ Furthermore, many in-

14. Mass Ann. Laws c. 151B $\$ 5$ (Supp. 1951); H.R. 4731, 82d Cong., 1st Sess. $\$ 7$ (a) (1951). The Massachusetts agency is the Commission Against Discrimination; the federal agency is the Wage and Hour Division of the Department of Labor. The Massachusetts law also provides for the filing of complaints by the state attorney general.

15. Mass. Ans. Laws c. $151 B \S 5$ (Supp. 1951) : H.R. 4731, \&2d Cong., 1st Sess. $\$ 7$ (a) (1951). Under the Massachusetts statute the hearing is held before the Commission itself. The federal bill on the other hand requires that the hearing be held before the Administrator of the Wage and Hour Division of the Department of Labor or "his duly authorized representative" H.R. 4731, 82d Cong., 1st Sess. $\$ 7$ (b) (1951). In either case final determination of the existence of age discrimination must be made by the Administrator himself. $I d$. $\S \S 7(\mathrm{~d})$ and (i).

16. Mass. Ann. Laws c. 151B $\$ 5$ (Supp. 1951); H.R. 4731, \&2d Cong., 1st Sess. \$7(i) (1951).

17. Mass. Ann. Laws c. 151B $\$ 6$ (Supp. 1951) ; H.R. 4731, 82d Cong., 1st Sess. $\$ 8$ (1951) (misnumbered in the bill as $\$ 9$ ).

18. Penalties are imprisonment for not more than one year, or a fine of not more than $\$ 500$ or both. The same sanctions apply for the wilful filing of a false complaint. Mass. Ans. Laws c. 151B $\$ 8$ (Supp. 1951). Both the Mlassachusetts law and the federal bill apply these penalties to anyone resisting or interfering with an authorized representative of the agency engaged in the performance of his duties. Ibid.; H.R. 4731, 82d Cong., 1st Sess. $\$ 14$ (1951).

19. Mass. Ann. Laws c. $151 B \S 1(S)$ (Supp. 1951). The prohibitory sections of the federal bill mention no limits, but the declaration of policy is against "... bias generally against workers over forty-five..." H.R. 4731, 82d Cong., 1st Sess. \$2(b). Section 6 (c) (7) provides that the purpose of the advisory and conciliation councils which the bill authorizes is to foster means "to fully utilize the skills of workers over forty-five..." In a letter to Director of Defense Mobilization Charles E. Wilson, Representative Javits speaks of his "introducing H. R. 4731 to prohibit discrimination in employment of vorkers over forty-five..." Press release of Representative Javits dated Aug. 26, 1951, on file in Yale.Law Library.

20. In a recent New York City survey two thirds of the job openings which had age limitations called for workers under thirty-five years of age. Two fifths of the openings required workers under twenty-five. EurEaU of Eurporaresir Secuntry, op. cit. 
dividuals over sixty-five do not wish to retire 21 and may be capable of matching the performance of the average worker in younger groups. ${ }^{22}$

Regardless of coverage, however, this legislation must meet problems which ordinary FEPC laws need not face. In barring distinctions based solely on race or religion, society declares that such criteria bear no reasonable relation to most job requirements. ${ }^{23}$ Discrimination because of age may, however, frequently prove justified. Thus employers may understandably prefer younger employees for jobs requiring a long period of training. Recognizing that such programs may pay off only as long term investments, the Massachusetts Commission has excused discrimination on this basis.24 $\mathrm{A}$ second possible

supra note 3, at 8. See also BARKIN, op. cit. supra note 3, at 194, where almost one fourth of maximum age hiring rules for men specified ages below forty-five; and Califorsis Departasent of Industrial Rejations, op. cit. supra note 4 at 40 , where almost one half of the limits were below forty-five.

BARKIN, op. cit. supra note 3, at 194, found that 71.4 per cent of maximum age hiring rules specified women below forty-five. See also California Departarent of Industural RELATIONS, op. cit. supra note 1 , at $37-40$.

For proof that discrimination under forty-five was well known to the Massachusetts Federation of Labor, which filed the Massachusetts bill, see Kelley, The Bay Statc Pioneers, The American Federationist, Nov. 1950, p. 14, where the Secretary-Treasurer of the MFL writes that the MFL "attracted statewide attention in the fight to have the bill passed by citing countless advertisements in newspapers specifying only 20 or 30 . year-olds need apply...."

21. Surveys of Social Security beneficiaries indicated that only about five per cent retired because they wished to do so. Furthermore, as of Jan. 1, 1950, about two fifths of all eligible workers were not receiving old age insurance benefits under the Social Security Act. Almost all of these had continued working or had returned to work after sixty-five. Bureau of Labor Statistics, op. cit. supra note 2 , at $7,10$.

Workers over sixty-five who wish to continue in their jobs face not only loss of old age benefits but the obstacle of private retirement plans as well. Insurance group-annuity contracts do not permit retirement ages over seventy. MACLEAN, LIFE INSURANCE 405 (1951). A common plan is for normal retirement at sixty-five and automatic retirement at sixty-eight with service beyond that age at the absolute discretion of the employcr. See, e.g., abstracts of retirement plans of American Tobacco Company (compulsory retirement at sixty-five), Chrysler Corporation, and Ford Motor Company (discretionary retirement by the company for inefficiency after sixty-five). U.S. Dep'r LABOR, Dicest of Selected Health, Insurance, Welfare, and Retirement Plans under Collective Bargaining 2, 10, 18 (1950).

For a typical statement against compulsory retirement see Indistrial Labs, Science, Jan. 3, 1947, p. 9.

22. Tests of mental and physical ability, while generally indicating the superiority of younger age groups, show an overlap in the distribution of ability between the younger and older groups. See, e.g., Edwards, Myth of Chronological Age, $34 \mathrm{~J}$. Appued Psyon. 316 (1950); Sorenson, Mental Ability Over A Wide Range of Adult Agcs, 17 Id. at 729 (1933). See also BARKIN, op. cit. supra note 3, at 332.

23. See U.S. Fair Empzoyment Practice Committee, Final Report 1 (1946).

24. Communication to the Yale LAw JouRNal, supra note 11. 
objection to older workers is their higher illness and accident rates. ${ }^{25}$ In addition to reducing their efficiency, older workers' more frequent disability may burden employers with slightly higher premiums under workmen's compensation insurance plans and non-compulsory health, accident and hospitalization insurance schemes. ${ }^{26}$ Furthermore, premiums under employer-financed

25. Kossoris, Absenteeism and Injury Experience of Older Worhers, 67 Mfor:THLY LAB. REv. 16, is (1948), gives the following figures covering work injury rates in manufacturing industries in 1945.

Age group
All age groups
Under 20
$20-24$
$25-29$
$30-34$
$35-39$
$40-44$
$45-49$
$50-54$
$55-59$
$60-64$
$65-69$
$70-74$

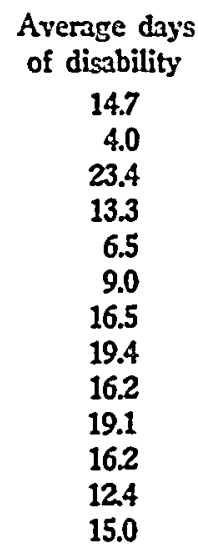

See also Barkin, op. cit. supra note 3, at 327-9; and Kossoris, Relation of Age to Industrial Injuries, 51 MontHLy LAB. REv. 7 S9 (1940).

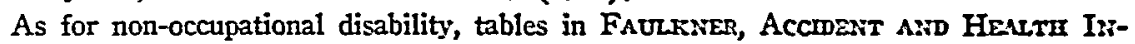
SURANCE 158-61 (1940), show marked increases in the incidence of accidents and sid:ness after age fifty. A survey of non-occupational disability in General Motors showed that male workers over fifty had almost three times as many non-occupational sicknesses as the younger group. Furthermore, the duration of each sichness was 50 per cent greater in the older group. In the case of women, no such discrepancies existed chiefly bacause younger women were frequently absent because of pregnancy. Gillen, Thic Cost of Employee Disability to the Employer, Industral Hygrene Foumdation Transactions Bulletron No. 15, The Huaran Stde of Industay 59 (1950). For similar findings in other industries see BARKIN, op. cit. supra note 3, at 329-31.

26. Experience rating is in general use in workmen's compensation insurance. While there are a number of variant forms, the essence of the plan is to produce an adjusted rate somewhere between the rate indicated by the firm's own accident experience and the rate indicated by the job classification, i.e., the manual rate.

For large firms the retrospective rating plan is available. Under this plan, the insured pays, within minimum and maximum limits, a premium based on his actual losses. Thus, within the limits, the insured in effect becomes a self insurer and receives no protection from insurance averages. Hobss, Workaren's Cosspearsation Insurantce 554-83 (2d ed. 1939).

State funds are either monopolistic or competitive with private insurance companies. In either case, however, their rating practices are similar to private companies. Id. at 331-6.

As for the various types of non-compulsory group health insurance, the basic rates 
life insurance plans are based on mortality and thus increase with age. ${ }^{27}$ Although added non-wage benefit expenses are partially mitigated by income tax deductions, ${ }^{28}$ in some firms hiring older workers may well increase overall benefit costs. Moreover, firms with liberal benefit schemes will be hit hardest. ${ }^{29}$ Neither the Massachusetts law nor the federal bill appear to sanction defenses based on these factors.

The most important justification of age discrimination is that in many cases age may indicate genuine differences in ability to do a particular job. The Massachusetts law requires the Commission to distinguish discrimination based on "occupational qualifications" from "unfair" discrimination because of age alone. ${ }^{30}$ But since the "occupational qualifications" phrase was in the

will usually vary with the makeup of the individual group. FAULKNER, op. cit. supra note 25 , at $180-1$.

Under some plans rates vary directly with age. See, e.g., Prudentind. Insurance: Co., Prudential Group Major-Medical Expense Insurance, brochure on file in Yale Law Library, where rates for employees between fifty-five and fifty-nine are almost four times higher than rates for employees under forty.

27. The cost of life insurance, ordinary, industrial or group, is dependent upon three variables: (1) the rate of mortality, (2) the rate of expense incurred including taxes, and (3) the rate of interest earned plus investment gain or loss. GregG, AN ANALYsis of Group Life Insurance 45-6, 136 (1950). Although workers tend to live longer than the average non-worker of the same age, the group mortality rate at fifty is over four times as high as at thirty. Id. at 49. See also MiAcLEAN, op. cit. supra note 21, at 396.

Group premiums are calculated by multiplying the rates for each age group by the number of members in each group. A fifty year old employee will be about twice as expensive to insure as a thirty year old. The final cost is usually based in part on the experience with the particular risk. Id. at 397.

Between 15 and 20 million workers employed by almost 50,000 firms are insturcel under group life insurance plans. GREGG, op. cit. supra note 27, at 141, 143; MEnR \& OsLer, MOdern Life Insurance 208 (1949).

28. Insurance premiums generally and out-of-pocket payments for employee injuries and pensions constitute deductible business expenses under INT. REv. Code § 23(a) (1)(A). Contributions by an employer to an employees' trust or amnuity plan are deductible under INT. REv. CoDE $\$ 23(p)$. But unprosperous firms will receive less benefit from the deductions since taxes are based only on net income.

29. For an indication that the costs of non-wage benefits are a factor in the setting of age limits, see Caimfornia Departirent of Industrial Relations, op. cit. supra note 4, at 42-7. Firms having some form of employee benefits had twice as high an incidence of maximum hiring age limits as firms which granted no benefits.

The motivation for setting age limits may be increased by the steadily rising cost of nonwage benefits generally. Compare the figures in U.S Chamber of CoMmerce, EConomic Research Departanent, Wage Supplements-The Nonwage Labor Costs of Doina Business 6-7, 13 (1950) with those in U.S. Chamber of Commerce, Economic Researcu Departarent, The Hidden Payroll-Non-Wage Labor Costs of Doing Business (1949).

30. Mass. Ann. Laws c. 151B. $\$ 4$ (1950).

Whether the federal bill contains a similar requirement is uncertain. Although the bill in its declaration of policy decries only discrimination against "properly qualified" 
FEPC law before the age amendment, the statute gives the Commission little guidance for its difficult task. Nor has the Commission itself set any specific criteria. ${ }^{31}$ Indeed, formulation of useful standards for determining whether a worker's age is relevant to his qualifications for a particular job may at present be impossible. Abstract tests show that mental ability, after reaching a peak at ages twenty to twenty-nine, declines gradually until the late forties or early fifties, and then sinks more sharply, ${ }^{32}$ while hand and eye tests demonstrate a decline in physical ability somewhere between thirty and forty. ${ }^{33}$

workers, H.R. 4731, \$2d Cong., 1st Sess. $§ 2(a)$ (1951), the statute itself proscribes age discrimination against "any individual" without using the modifying words of the preface. $I d$. $\$ 5$.

31. Under the Commission's policies a bona fide job qualification may be determined either by the Commission upon request of an employer, who must furnish the Commission with such information as it may request, or by the employer himself. In the latter case, when a complaint is made the burden is on the employer to prove the "validity" of the qualification. Massachusetts Commission Against Discrnannation Polictes $\S 10 \mathrm{C}$ (mimeo. Feb. 1951).

32. Sorsenson, sutpra note 22 at 729. See Thorndike. Adult Learniric 131 (1928), where the author finds that "at about fifty-five the net result of changes in general energy, interest in one's work, and ability to improve is a regression in achievement." See also Lawton, Mlenfal Abilities At Senesconce: A Suricy Of Present-Day Rescareh, 22 J. Applied Psych. 607 (1938).

Vocabulary is the one exception to mental decline in senescence. Sorenson, suspro, note 22. Tests of memory show a 17 per cent decline from peak efficiency during the years fifty to sixty-nine; tests of judgment show a 13 per cent decline. Miles, Age and Humass Ability, 40 Psycr. Rev. 99, 114, 116 (1933). See also Kuch, The Differentiatre Effects Of Age Upon Hzman Leaming, 11 J. GeN. Psych. 261 (1934).

Much work has been done from a historical angle to determine at what ages great men do their best work. See, c.g.. Lehman, Man's Most Crcatize Years, 59 Scr. MoriryLy 384 (1944), where superior contributions in geology, psychology, opera composition, short story writing, poetry, education, economics, political science, mathematics, inventions, hymn composition, and chemistry were all found to have been made most often at about thirty-five years of age. Similar results were obtained in the analyses of contributions in physics, botany, pathology, classical descriptions of disease, medicine, public hygiene, philosophy, and literature. Lehman, Man's Most Creatize lears: Then and Now, 98 Scr. 393 (1943). But see Bjorksten, Comments and Crilicisme, 62 Sa. Mosirnly 94 (1946), who argues that these findings could merely be the tesult of the press of increased administrative duties that come with age and success.

Age also affects personality. See generally Jones, Personality and Agc, 136 NArURE 779 (1935). There is evidence that older people are more conservative. See Pollak, Conservatisn in Later Maturity and Old Age, \& Ax. Soc. Rev. 175 (1943). Pcople in older age groups have been found to be more serious minded and self restrained. Women seem to tend towards unpleasant moods and feelings in old age. Guilford \& Martin, Age Dijferences and Sex Differences in Some Introvertize and Emolionol Trails, 31 J. Gen. Psycr. 219 (1944). Older people generally tend to be more variable in their traits. Preston, Trait Variability as a Function of Practice and of Age, 37 J. GEN. PsxcB. 3 (1947).

33. Reach and grasp tests show a 12 per cent decline from peals efficiency in the fifty to sixty-nine age group. Rotary motility has been found to decline 11 per cent. When reaction was tested by an experiment requiring a downward press of the finger, the usual 
Tests simulating industrial work show a similar and sometimes more extreme decrease in physical ability with age. ${ }^{34}$ But evidence as to the comparative productivity of older and younger workers in actual job situations is almost entirely lacking. ${ }^{35}$ And the significance of the little data available is unclear. ${ }^{30}$

age curve appeared. But other reaction tests showed no appreciable drop in the fifty to sixty-nine age group. In all these tests the age group above sixty-ninc was about 30 per cent below peak efficiency. Miles, Mcasures of Certain Human Abilitics Throughout the Life Span, 17 Proc. Nat. Acad. Scr. 627 (1931). See also Miles, Age and Human Ability, 40 Psycr. Rev. 99, 113 (1933), and Miles, Correlation of Reaction and Coordination Speed with Age in Adults, 43 Arr. J. Psycri. 377 (1931). In tests of finger tremor, a sixty to eighty-five year old group showed a 19 per cent increase over a group sixteen to thirty-five years old. Edwards, supra note 22, at 316.

The efficiency of all measurable functions of the eye decreases with advancing age. See generally Friedenwald, The Eye in Problems of Agerng 535 (Cowdry ed., 2d cd. 1942). Visual acuity has been found to decrease as much as 30 per cent between fifty and sixty years of age. Id. at 537. Visual sensitivity as revealed by the light threshold also shows a decline. Birren, Bick, \& Yiengst, The Relation of Structural Changes of the Eye and Vitamin A to Elevation of the Light Threshold in Later Lifc, $40 \mathrm{~J}$. Experimental Psych. 260 (1950). Adaptation to the dark declines progressively until forty and then drops more sharply. Steven, Dark Adaptation and Age, 157 NATURE 376 (1946). Ability to discriminate colors by hue, saturation and lightness shows a marked declino after fifty. Smith, Age Differences in Color Discrimination, 29 J. Gen. Psxcir. 191, 204 (1943). Tests of color blindness show an abnormally high rate after sixty. Boice, Tinker, \& Paterson, Color Vision and Age, 61 Ax. J. Psych. 520 (1948). Glare vision shows a heavy drop after age thirty. DeSilva, Age and Highway Accidents, 47 Scr. Montuly 536 (1938).

Tests of the fusion frequency of flicker, i.e., the number of rapid flashes of light that can be seen separately rather than as a steady illumination, show a drop in the average and maximum rates, while the minimum rates for all age groups stay relatively the same. Simonson, Enzer \& Blankstein, The Influence of Age on the Fusion Frequtency of Flicker, 29 J. Experimental Psych. 252 (1941). See also Misiak, Age and Sex Differences in Critical Flicker Frequency, 37 Id. at 318 (1947).

34. Smith, Age and Performance on a Repetitive Manual Task, 22 J. Applied PsYcir. 295 (1938). In this very thorough experiment, tests consisting of the assembling and disassembling of bolts and nuts were made of four age groups. In addition to a short test period, measurements were taken over a four hour span, and financial incentives were provided so as to simulate actual working conditions. During the four hour period fifty year olds were on the average 13.5 per cent inferior to thirty year olds, in contrast to an 8.1 per cent inferiority in the shorter period. However, 15 per cent of the fifty year olds were equal or superior to the median thirty year old man. The work curve at fifty years showed no tendency toward relative slowness in warming up at the beginning and no relative drop at the end of the work period. See also Ehinger, Declin des Aptitudes avec $L^{\prime} A g e$, ArCerves DE Psychologie, 23, 67, 73 (1931-32). Tests of bead stringing, paper cutting and disc placing showed a fifty year old group to be 6.7 per cent to 19.4 per cent inferior to a thirty year old group.

35. See Bureau of Labor Statistics, op. cit. supra note 2, at 16.

36. See Cover \& Pressy, Age and Route Sales Efficiency, 34 J. Applied Psycr. 229 (1950). Here performances of house to house salesmen of foodstuffs were evaluated. Older men as a group, while more careful operators of the company vehicles, fell off markedly in the amount of sales. See also studies of hourly earnings in BARKn, op. cit. 
While information gleaned from tests is suggestive, it is an insufficient guide for setting standards. ${ }^{37}$ This uncertainty saps the Massachusetts law's effectiveness. Lacking both statutory and scientific tests of whether discrimination is justified, the Commission has, thus far, usually assented to the claim that the applicant lacked the requisite ability. ${ }^{38}$

Even if more accurate information as to older workers' abilities were obtained, FEPC legislation could probably do little to solve the age discrimination problem. Where older workers were proved fully qualified for certain jobs, FEPC would no doubt be effective. But indications are that for most jobs older workers would be found less efficient; in these circumstances the law permits discrimination. Thus an adequate solution to the age problem must be sought elsewhere. If present high-employment economic conditions continue, the efforts of welfare organizations and collective bargaining, if augmented, may be adequate to ensure the hiring of older people. But in an economic recession, ${ }^{39}$ if the government's overriding objective is employment of older workers, it might be necessary to pass laws requiring employers to hire specified percentages of older workers-as is now done under some labormanagement contracts. Forcing older workers on employers, however, might leave abler younger workers unemployed, thus lowering the productive apacity of the nation. A better solution might be to provide a program of public works for the needy aged. Before any new approach is tried, however, the government should make an exhaustive study of the role of the older

supra note 3 at 332 et seq., which shows peak productivity to be reached in the thirty-five to thirty-nine age period. However in Palmer \& Brownell, Influence of Age on Enployment Opportunities, 48 MIONTHLY LAB. Rev. 765 (1939), the authors conclude that there is no clear relation between age and output for those workers who can maintain minimum production standards.

37. See Clague, The Job Outlook for Older Workers, The American Federationist, Nov. 1950, pp. 29, 30, where the United States Commissioner of Labor Statisties advocates a systematic study of the on-the-job abilities of older workers to fill " 3 great dearth of factual information on a number of key points."

38. Up to Jan. 10, 1952, the Commission had disposed of thirteen cases. The Commission found lack of probable cause in 7 cases, a lack of jurisdiction in 2, and 4 cases were settled "after investigation and conference" Ninety-four requests "have given reasons to warrant an exemption based on a bona fide job qualification." Communication to the Yale Law JourNal from Mildred H. Mahoney, Chairman of the Massachusetts Commission Against Discrimination, dated Jan. 10, 1952 on file in Yale Law Library.

39. "A continuing special problem of employment for older workers tends to persist through good times and bad. However, both the magnitude and nature of this problem are greatly affected by changes in the general employment situation.

$\neq \neq *$

"In the early postwar years of high levels of employment, unemployment among older workers approached minimum levels." Clague, supra note 37, at 29.

For a good statistical presentation of the problem of the older worker in a period of depression, see Comarissioner of Labor and Stattstics of Miaryland, Tre Olfar WORKER IN MARYLAND (1930). 
worker in our prospective economy. ${ }^{40}$ Meanwhile, without supplementary measures, FEPC promises relief for only a tiny proportion of older people and nothing but false hopes for the rest. ${ }^{41}$

40. See Clague, supra note 37 , at 30.

41. It was fundamentally for this reason that the New York State Joint Legislative Committee on Problems of the Aging rejected an anti-discrimination law as a solution. See Findings and Recommendations, supra note 11 , at 29. 